\title{
Понятійно-категоріальна система сучасного українського мистецтва в новій естетичній парадигмі XXI століття
}

\author{
TETЯHA MIPOHOBA \\ канАиАат мистецтвознавства, Київська міська галерея мистецтв «^авра», Аиректор \\ orcid.org/0000-0002-8847-1100
}

\begin{abstract}
Анотація. Оновцення тематичного та стилістичного розмаїття візуацьних мистецьких проявів зумовицо оновцення понятійно-термінологічного та категоріального апаратів у сучасній мистецтвознавчій науці. Сучасне мистецтво є оАним з найбільш Аинамічних культурних феноменів сьогодення, тож його дослідження постійно потребує оновлення осмислення та засобів анаАізу заАля орієнтації у його величезній кількості видів, напрямів та жанрів. Розвиток сучасного мистецтва нерозривно пов'язаний із технічним прогресом, цифровими інноваціями, при цьому у своєму традиційному спрямуванні мистецтво постійно перебуває у пошуку нових форм, вигадує нові жанрові системи, грає з контрастами та експериментує з матеріалами. Немає сумніву, що всі ці процеси є цікавими Аля сучасних науковців і насампереА мають бути регламентовані певною термінологічною системою.

Ключові слова: термінологічний апарат, сучасне мистецтво, contemporary art, технологічний прогрес.
\end{abstract}

Постановка проблеми. Неоднорідність сучасного українського мистецтва зумовлює виникнення низки розбіжних течій, напрямів і явищ, що потребують оновлення та узгодження понятійно-категоріального апарату та нових піАходів Ао їх наукового АосліАження. Оновлення піАходів Ао вивчення мистецтва contemporary насампереА викликане новими засобами художнього пошуку митців, що призвели Ао оновлення образотворчих прийомів. Чимало художників сьогоАні віАмовцяються віА точного змалювання реацьності, звертаючись до експериментів, творчих асоціацій та філософських АосліАжень, віАходячи віА зображальних мистецтв Ао сфери візуацьного, а точніше, віА раціональної творчості - ло ірраціональної та інтуїтивної. Означена тенденція сформуваца одну з головних характерних рис контемпорарного мистецтва і по суті сформувала образотворче мистецтво межі XX-XXI ст. Оскільки при АосліАженні сучасного мистецтва завжАи необхіАно враховувати, що пізнавальні конструкти, у пара-
Аигмі яких зАебільшого працює вітчизняна наука, створені ще в епоху модерну і сьогодні піА впливом Аокорінної трансформації суспільного буття

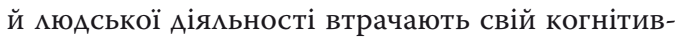
ний потенціал і дієвість [10], то систематизація та встановцення узагальненого термінологічного ряАу Аля АосліАження сучасних візуальних мистецтв $€$ першочерговим завАанням сьогоднішнього мистецтвознавства.

Мистецтво $є$ специфічною формою світосприйняття, що формує концептуальну картину світу Аля суспільства залежно віА зміни епох та технічного прогресу [10]. Важмивою специфічною характеристикою твору мистецтва межі XX-XXI ст. $€$ його спрямованість на гляАача, віАкритість та комунікативність. Воно ж вимагає віА реципієнтів певної освіченості та художнього смаку, таким чином розАіляючи сфери свого впливу між мистецтвом масовим (візуацьним) та елітарним (мистецтвом художніх образів). Ще з середини 1930-х років елітарна і масова культури стають 
основним преАметом АосліАжень іспанського фімософа Х. Ортега-і-Гассета, який зосереджує увагу

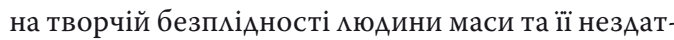
ності до гАибокого осмислення реальності. Говорячи про сучасне мистецтво, Х. Ортега-і-Гассет звертає особливу увагу на «принципово непопуАярний» його різновиА, який нікоми не стане Аоступним масовій свіАомості і не втратить свого змісту піА впливом стандартів [13]. АосліАження іспанського філософа означили низку кцючових тенденцій розвитку візуального мистецтва віА самого його зародження, початку авангарАних течій (нефігуративного мистецтва), і актуальні донині. «Аегуманізація» в розумінні філософа означала неможмивість сприйняття нових (на той час) творів та співпереживання глядачів їхнім образам (позаяк в переважній бікьшості вони були віАсутні), що призвело Ао творчих трансформацій художників, спрямованих на відхіА віА копіювання реацьності. На думку Х. Ортега-іГассета, сучасне мистецтво викмючимо АюАину, а саме гуманістичні настрої, що пануваци в натурахістичній та романтичній художніх практиках у попередні епохи. ЄАиним «чистим мистецтвом» фікософ вважав абстрактне, аАже демонстроване у творах мистецтва уникнення реацьності заперечує характерні Аля бімьшості глядачів співучасть і переживання, а «твір мистецтва, що не спонукає до такого втручання, залишає їх байдужими» $[13$, с. 48]. Таким чином, фікософ позначив найважмивіший аспект розвитку мистецтва та культури у ХХ столітті загацом - визначення межі між елітарним і масовим, а отже, застосовуючи його концепцію Ао сучасних реаАій, - між традиційним та інноваційним, між хуАожнім образом та візуацьним.

Анаціз попередніх досліджень та пубцікацій. Осмисленню загальних питань розвитку мистецтва присвячені роботи низки виАатних Аіячів гуманітарної науки, зокрема відомих філософів А. Аанто, М. Мерло-Понті, Ж. Аемьоза, Ж. БоАріяра та ін. Кумьтурологічною базою при АосліАженні та вивченні основних Аефініцій сучасного мистецтва в епоху цифрових та інформаційних технологій стали публікації 3. А^фьорової, В. Бичкова, Н. Маньковської, Г. Скцяренко, В. Скуратівського, В. Сидоренка та інших.

Основний текст. Вплив науково-технічного прогресу на зображення навкомишнього світу в художніх образах досліАив американський вчений і філософ А. Аанто в роботі «Твір мистецтва та історичне майбутнє» [19]. Зокрема, він вказує на безпосередній зв'язок між технічним прогресом та оновленням артпрактик і зазначає, що ці процеси відбуваються паралельно один одному. Розмірковуючи наА змінами образотворчості, теоретик окрему увагу придікяє абстрактному та концептуальному мистецтву як таким, що менше рефлексують на зовнішні впливи і залишаються в рамках художніх традицій. Так, головним питанням у своїй роботі А. Аанто ставить розуміння твору мистецтва як такого, вважаючи, що мистецькими творами сьогодні необхіАно вважати усе, що називається «мистецтвом». Розділення мистецьких практик на «історичні» (традиційні, рефлексуючі) та «постісторичні» (абстрактні, концептуацьні, нерефмексуючі) не заважає йому називати ці обидва напрями мистецтвом, а порушує важмивий аспект оновцення теоретичного осмислення цього питання віАповідно до вказаного подіку. Саме це, на Аумку філософа, Аозволить нарешті зрозуміти процес розвитку мистецтва як у кумьтурноісторичному, так і в образно-понятійному планах. Розмірковуючи про взаємовплив історичного прогресу та тенАенцій розвитку сучасного мистецтва, А. Аанто піАкреслює, що зазначений ним «плюралізм у сучасній художній культурі не перекреслює історичний прогрес, а навпаки - сприяє вивіАьненню художників та мистецтва як такого віА стимістично та жанрово маркованих рамок» [19, с. 176].

На противагу переконанням А. Аанто, французький філософ Ж. Бодріяр вважає, що широка орієнтованість мистецьких напрямів призводить Ао практичного нівецювання мистецтва, його посередності та вторинності. Навіть абстрактноконцептуахьний напрям як новий естетичний рівень, на Аумку Аослідника, не скасовує цього 
процесу, аАже «...мистецтво, що розігрує власне зникнення та зникнення об'єкта, - все ще можна вважати великим мистецтвом. <...> Сучасне мистецтво зАебільшого практикує саме безкінечне віАтворювання, жорстоко розправцяючись із реацьністю, засвоює банацьність, непотріб, посереАність, вбачаючи в цьому систему цінностей і ідеологію. Нечисленні інсталяції та перформанси $є$ нічим іншим, як грою на компромісі зі станом речей, так само, як і з усіма минулими формами мистецтва. Оригінальність, банальність та ницість, претендуючи на статус цінності, виАають себе за естетичну насолоду» [4]. Вважаючи сучасні концептуальні мистецькі напрями абсолютним злом, філософ при цьому виокрем$\Lambda ю €$ «мистецтво зникнення сенсу» як винятко-

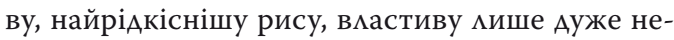
багатьом роботам і мистцям. Вони, на Аумку автора, спроможні незначність та ницість зробити подією, перетворюючи їх на фатальну образотворчу стратегію. Так вияв яється Ауацьність сучасного мистецтва: беззмістовне Аоведення беззмістовності, яке суспільство при цьому приймає та сприймає як справжнє мистецтво, сфальсифіковане і без сенсів: «Коли ніщо виходить на поверхню, зростаючи у систему знаків - маємо справу з фундаментальною подією в мистецтві» [4]. Водночас стратегія усіх інших функціонерів мистецького процесу, за Ж. Бодріяром, - не більш ніж комерційна та рекцамна «параноя мистецтва», заснована на вербальних та невербальних описах Аругорядних арткритиків та загорнута в мішуру вернісажів, тусовок, виставок, фуршетів, колекцій, меценатів і т. ін. Увесь цей процес філософ називає «змовою мистецтва», керованою і підтримуваною «зАочином посвячених», спекулюванням на тих, хто на мистецтві не розуміється, іншими словами, «мистецтво вкцючилось (не мише з точки зору фінансових аспектів художнього ринку, а й при визначенні естетичної якості) в загацьний процес, Аетермінований посвяченими. Так, політика, економіка, інформація таким же чином передбачають залучення вузького кола спільників і викцикають настіль- ки ж покірливе і одночасно іронічне ставлення потенційного «споживача» [4]. У своїй роботі Ж. Бодріяр наче Аискутує зі своїм співвітчизником М. Мерло-Понті, який був опозиційно налаштований Ао мистецтва репрезентативного, аАже «натуралістичні концепції звоАять мистецький знак Ао знаку природного і намагаються обмежити мову виявом емоцій» [12, с. 185], вважаючи концептуалізацію образотворчості «здатністю оформлювати викмики та події найвищим рівнем мови» [12, с. 185]. АосліАник вважав, що художнику мало бути філософом і творцем, завданням художника, на його Аумку, $\epsilon$ не імітація або репрезентація, - він має вміти пробуджувати АосвіА у свідомості інших [21, с. 61], а гАяАач - мати змогу його сприйняти та зрозуміти. Тож, художні засоби, на Аумку М. Мерло-Понті, розширюючи спектр виразності, вимагають віА реципієнта високого рівня мислення - не поверхневого бачення, а саме заглибленої думки, що її дослідник порівнює зі своєріАним «архівом» образів, який зберігає «зображення» речей як образи, що безперервно Аіють і реагують оАин на оАного, продукують та споживають. Ці образи мають свій внутрішній простір і відчуваються та сприймаються підготованим глядачем «зсередини», на чуттєвому рівні [8].

Як художня критика, так і мистецтвознавча наука сьогодні прагнуть знайти узагальнене визначення явища / феномена / Аефініції contemporary art («сучасне мистецтво»), яке в науковій $і$ ітературі трактують Аоволі неоднозначно, неріАко як розширене означення «актуального мистецтва». Образотворче мистецтво постійно змінюється піА впливом історичних, соціальних, політичних, наукових і технологічних факторів. На межі XX-XXI ст. естетична модель мистецтва оновююється, розширюючись за рахунок глобалізації культури, а також поглиблення проблем екологічного та соціокультурного характеру; мистецтво комбінує художні прийоми і техніки, його часто тиражують і відтворюють у різних формах, а рівень підготовленості глядацької аудиторії визначає межу елітарного і масового. Так, характеризу- 
ючи мистецтво ХХ ст., німецький філософ В. Беньямін вказує, що мистецтво в час розвитку технологій продукує велику кількість методів, форм і засобів виразності, а фотографія, відеоарт, темебачення та інтернет стають основними засобами поширення сучасного мистецтва, адже саме вони беруть участь як у глобальному виробництві, так і в споживанні культури. Філософ вказує, що «з появою різних технічних методів експозиційні властивості мистецтва зросли настільки сильно, що якісно змінили його природу» [3, с. 76]. Порівнюючи сучасне образотворення з первісним мистецтвом, основою якого була культова функція, В. Беньямін означує його експозиційну роль, що робить його новим явищем із абсолютно новими функціями, з яких естетична найчастіше стає супутньою. На його Аумку, в епоху технологічного прогресу фото- і віАеоарт стають важмивими засобами зв'язку творів мистецтва 3 культурним Аосвідом аудиторії. Таким чином, можАиво несподівано, в роботах філософа розрізняється мистецтво, зрозуміле широким масам (яке надалі назвуть public art), та мистецтво елітарне, Аоступне Аля глядача з певним споглядальним досвіАом. Мистецтво публічне (експозиційне) суспільство сприймає в загальному контексті, часто залежно віА соціокультурних обставин та з урахуванням прикладних функцій [18, с. 217-218]. Теоретичні висновки В. Беньяміна Аають змогу зробити акцент на розподілі статусності художніх творів сучасного мистецтва, адже втрачена в мультимеАійному мистецтві «аура» неповторності компенсується у новій формі, у нових просторово-часових контекстах, на межі між «оригіналом» і «копією». «Аемонстрація арт-продукту на різних реальних і віртуацьних майданчиках розширює початковий контекст і семантичні межі твору. Таким чином, традиційне есенціальне розуміння сутності твору мистецтва заступає розуміння експозиційне: сенс мистецтва сліА шукати не в ньому самому і його художній цінності, але в просторі його експозиції, що формує нове художнє мислення - серійність його сприйняття» [9]. Ця серійність у минулому зАебільшого природно проявцянась в мистецтві графіки, оАнак сьогодні бачимо ії уже в будь-якому виді образотворення, позаяк новітні технології дозвоАяють множити й такі традиційні виАи мистецтва, як скульптура і живопис. При цьому це множення проявцяється не в простому копіюванні, а «розгортається в умовах серійності та автоматичності погАяду та сприяє накопиченню смисмів і значень: скмадаються нові системні відношення між цими компонентами» [1].

У. Еко наголошує, що особливості різних типів художніх повторень (маючи на увазі і серійність, і копіювання), преАставлених в історії мистецтва, сліА враховувати піА час АосліАження критеріїв хуАожньої цінності сучасних творів як певне явище, що визначає сучасність як «епоху повторень». Аос іАник виАіляє в мистецтві низку сформованих типів повторень, як-от: «retake» (повторна зйомка), «remake» (переробка), «серія», «сага», «інтертекстуацьний Аіалог» та ін. На переконання фімософа, естетичне задоволення глядач має отримувати віА усвіАомлення того, як твір зроблений, віА упізнавання знайомих мотивів, віА вибудовування інтертекстуальних зв'язків із соціальними змінами [16; 9], а не віА безкінечних описових концепцій, заснованих на надмірності. Такі наративні твори запрошують глядача насампереА відпочити та розважитись, а розумовий процес стає АругоряАним. Водночас філософ піАкреслює, що «оАнотипні повторення можуть породити як Аосконалість, так і банальність: вони можуть змусити глядача вступити в конфмікт із самим собою і $з$ iнтертекстуальною традицією загалом; вони можуть Аати йому втіху, проекцію і безпроблемне впізнавання; вони можуть укмасти особливу угоАу 3 наївним або грамотним читачем, або навіть з обома одночасно на різних рівнях континууму рішень, який неможливо звести до рудиментарної типології» [15, с. 51]. Акцент при цьому зроблено на відкритості сучасних творів Аця аудиторії будь-якого рівня, без прив'язки Ао жорстких моделей та встановлених обмежень. ТранскорАонними елементами новоутвореного естетичного простору стають елементи гри, іронії, кри- 
тики, що породжують змішання елементів масової культури та елітарної і нівелюють Аистанцію між аудиторією і мистецьким твором, згуртовуючи публіку навколо себе. В цьому аспекті художники (особливо в творах public art) все більше звертаються Ао широких мас, на противагу переконанню Х. Ортега-і-Гассета, що «нове мистецтво» має зустрічати неприйняття, розАіляти суспільство. Найважливішим аспектом сприйняття творів мистецтва XX ст. $є$ факт, що реципієнтами тепер стають не тільки окремі особистості, а й великі і малі соціальні групи [13]. Творчість художників у сучасному мистецтві орієнтована на широку аудиторію, а не на конкретного глядача.

Аоктор філософських наук В. Бичков, характеризуючи сучасне образотворення, посилається на слова естетика Аж. Аікі: «Мистецький твір це об'єкт, про який хтось сказав: я називаю цей об'єкт твором мистецтва». Він вказує на розмиття критеріїв оцінки сучасного мистецтва, адже естетичність та краса вже не $\epsilon$ критеріями у традиційному смислі: сучасне мистецтво, за тверАженням В. Бичкова, «вже часто і не називає себе мистецтвом, а арт-практиками, арт-проєктами, артвиробництвом та ін., віАмовилось віА головних естетичних принципів образотворення: міметизму, символізму та відповіАно віА художньої образності, орієнтації на духовні реалії, красу та величне, майже повністю Аегуманізувалося» [5, с. 10]. «ВіАкритий твір» сучасного мистецтва сприяє усвіАомиенню особливої свободи в глядача, спонукає його Ао формування власної моделі світу [16, с. 107]. Така позиція піАтверАжує, що твори сучасного мистецтва ініціюють розширення пізнання і розвивають уяву, активізують потребу в усвіАомленні свободи індивіда як частини соціального світу, але $\epsilon$ й інша «сторона меАалі», позаяк усе перелічене призвело Ао поширення в сучасному мистецтві маргінальності, симуляцій, інтертекстуацьності, полістилізму, цитатності, змішання форм елітарної та масової культур, а отже, панування кітчу і кемпу, нівелювання традиційних ціннісних критеріїв та перебільшення фігури художника.
Окресливши магістральні тенденції розвитку сучасного мистецтва як «орієнтованість на широкі маси» та «віАкритість», розглянемо та уточнимо термінологічний апарат, який буде визначацьним у подальшому досліАженні. 3. А^фьорова, поряд 3 уже традиційним Аля означення творів сучасного мистецтва поняттям «об'єкт», використовує термін «артефакт» (віА $а$ ат. ars - ремесло, мистецтво i factum - зроблене) Аця визначення творів мистецтва, які виходять за усталені морфологічні межі і $є$ продуктом трансгресивних хуАожньо-мистецьких практик [2].

«Найкмасичнішим» терміном при згадках про сучасне мистецтво $є$, звичайно, така особлива форма організації окремих елементів, що поєАнує їх єАИним смислом, в єАиний мистецький об’єкт, як артінсталяція (віА англ. to install та франц. installation встановлювати). Часто термін «інстацяція» замінюють дефініціями land art та environment design, говорячи про мистецький твір, створений у природному мандшафті. Визначаючи інстацяції як жанр мистецтва XXI ст., $\Lambda$. Вольська та Н. Ковацьова тлумачать їхні технічні аспекти, застосовуючи Аiєслова «встановлювати», «скиадати», «формувати» (мистецький твір з окремих різноріАних частин) [7]. Історично інсталяції скмадали з готових (побутових) предметів і «переносици» реацьні речі у музейний простір, а з розвитком мистецтва і технологій до реальних преАметів додалась віртуацьна скцадова.

3 появою штучних оптичних систем - посередників між оком та Аійсністю - почала збагачуватись і термінологічна система мистецтвознавства, невідповіАність і нечіткість якої призвели спочатку Ао порушення фахових контактів та розбіжностей у тлумаченні мистецьких процесів [2, с. 166-170]. Так, «віАкритість» сучасного мистецтва, в сукупності з розвитком інформаційних та цифрових технологій, зумовила закучення Ао термінологічної системи образотворення поняття «медіа». У звичайному розумінні медіа (віА лат. medium - середній, посередник) це інформаційний канац або засіб масової комунікації (3МI), воно вкцючає засоби комунікації, 
засоби передачі інформації, а також створюване ними певне середовище - медіапростір. У контексті ж сучасного мистецтва цей термін здебільшого вживають Аля означення технічних засобів, а також орієнтованості на велику аудиторію. Так, Аослідник термінології медійної сфери А. Федоров вказує, що «медіа» - це засоби масової комунікації: «технічні засоби створення, запису, копіювання, тиражування, зберігання, поширення, сприйняття інформації та обміну її між суб’єктом (автором медіатексту) і об'єктом (масовою аудиторією)» [14, цит. за 17]. «Функція інформування в цьому випадку виконує Аругорядну роль, а на перший план виходять можливості меАіа встановлювати зворотний зв'язок між глядачем і автором, а також зв'язок між глядачами за Аопомогою технічних засобів, посилюючи значення розважальної та просвітницької ролі» (за М. Маклюеном, виховної. - Т. М.) [11, с. 124-163].

Аослідниця феномену медіаекономіки О. Вартанова, розширюючи функціональне навантаження дефініції, визначає медіа як «засіб зАійснення комунікації між різними групами та постачання будь-яких змістовних продуктів аудиторії». Також вона класифікує медіа на засоби масової інформації (газети, журнали, книжки, телебачення, кабельні мережі, радіо, кінематограф), окремі носії інформації і даних (листи, аудіо- та відеозаписи на будь-яких носіях, компакт-Аиски), комунікаційні системи суспільства (телеграф, телефон, пошта, комп'ютерні мережі) [6, с. 73], акцентуючи увагу на значенні терміну як «посередника». У подальшому дослідженні ми використовуємо максимально широке визначення терміну «меАіа» як комплексу технічних засобів та новітніх технологій, що Аозволяє створювати, редагувати і передавати інформацію та здійснювати комунікацію в суспільстві.

Слідом за дефініцією «медіа» в науковий обіг увійшов термін «медіамистецтво» («медіаарт»), який інспірував виникнення терміну «медіахудожник». У науковій та науково-попумярній мітературі це поняття трактують по-різному, часто синонімічно до всього технічного арсенацу створення: «відеоарт», «аудіовізуальні мистецтва», «екранні мистецтва» та ін. А. ФеАоров, наприклаА, у своїх Аослідженнях визначає його як «різні комунікативні мистецтва, побудовані на меАійних образах, тобто образах, створюваних засобами відтворення Аійсності» [14, с. 18]. Такими засобами досліАник називає Арук (принт), фотографію, відеозапис, кіно, телебачення, відеоарт, комп'ютерну графіку та ін. Об'єАнавчим фактором тут стає саме специфіка «медійного образу», створюваного цими засобами, а не вибір використаних технічних засобів. Попри різну техніко-технологічну основу, а отже, і специфічний творчий інструментарій, сьогодні художні практики із застосуванням медіазасобів розглядають як загальне поле творчих експериментів (що інколи не виходить навіть за межі цього експерименту, переходячи в сферу «художніх практик») на піАставі нових іАей, концепцій, специфіки художнього мислення та художньої мови. Аослідження взаємодії артпрактик та мистецтва визначає оновлення специфіки мистецького процесу, адже художня практика - це, по суті, процес, взаємодія між автором і твором, між твором і глядачем, а відтак між глядачем і автором - невикцючний елемент художнього творіння, але їі результатом не обов'язково буде мистецький твір у традиційному розумінні. Близьким до медіамистецтва за значенням та часом виникнення $\epsilon$ термін «мультимедіа». Частіше за все в науковій $\Lambda$ тературі його застосовують Аця позначення робіт, створених за Аопомогою електронних засобів. Цей термін охоплює і комп'ютерну техніку, в якій реамізований набір засобів, необхіАний Аця обробки аудіовізуальної інформації. Прикметник «мультимедійний» щодо твору медіамистецтва означає, що твір поєАнує в собі кілька, найчастіше цифрових, технологій і скмадається з різних компонентів, таких як звук, текст, графіка, анімація, віАео, інтерактивність.

«Найсвіжішим» за часом появи в науковому обігу $є$ термін «нове медійне мистецтво». Його ввів у 1994 р. медіахудожник і теоретик мистецтва М. Трайб, позначаючи наступ нового етапу розвитку медіамистецтва, в якому використано 
нове покоління медіатехнологій — нові медіа. Ще одним із перспективних напрямів у застосуванні сучасних медіаформ $\epsilon$ «трансмедіа» - поєАнання різних медіа, таких як телебачення, вебсайти, соціальні мережі, комп'ютерні ігри та ін. У художній практиці трансмеАіа застосовують як новий спосіб нарації, що Аозвоцяє розширити концептуальний простір, а також посилити особисту участь гляАача в розкритті наративу [17]. Розвиток комп'ютерних і цифрових технологій, що Аозволяють сьогодні художникам створювати нові просторові виміри, а віАтак і нову реальність, привели до появи у термінологічному апараті сучасного мистецтва терміну «віртуальний» (англ. virtual reality віА virtual - фактичний; $а$ ат. virtus - потенційний, можмивий, уявний; $а т$. realis - речовий, Аійсний, існуючий) - технічно сконструйоване за Аопомогою комп'ютерних засобів інтерактивне середовище, симуляцію самостійної присутності АюАини у просторі і часі, створену засобами спеціацьного комп'ютерного устаткування [2, с. 167]. Всі означені напрями розвиваються в річищі глобальної тенденції XXI ст., що полягала в руйнуванні меж між різними середовищами, змішуванні виражальних засобів різних виАів мистецтв.

Висновки. ОАним із першочергових у теоретичному Аискурсі естетики й фікософії мистецтва залишається питання формулювання дефініції «сучасне мистецтво». Осмислення теоретичного піАгрунтя мистецтва як форми відображення
Аійсності Аозволить виявити певні контекстуальні закономірності, що Аіють та розвиваються в культурологічних вимірах наприкінці XX - на початку XXI ст. Сучасне мистецтво $€$ одним з найбільш Аинамічних культурних феноменів сьогодення, тож його АосліАження постійно потребує оновмення осмислення та засобів аналізу заАля орієнтації у його величезній кількості виАів, напрямів та жанрів. Розвиток мистецтва contemporary нерозривно пов'язаний із технічним прогресом, цифровими інноваціями, при цьому у своєму траАиційному спрямуванні воно постійно перебуває у пошуку нових форм, вигадує нові жанрові системи, грає 3 контрастами та експериментує з матеріалами. Немає сумніву, що всі ці процеси $€$ цікавими Аля сучасних науковців і насампереА мають бути регламентовані певною термінологічною системою.

У процесі формування понятійно-категоріального апарату сучасного образотворчого мистецтва важливу роль зіграци філософські роздуми Ж. Бодріяра, М. Мерло-Понті, Х. Ортега-іГассета та ін. Теоретичні основи, запропоновані в рамках їхньої філософської рефлексії, отримами розвиток у мистецтві постмодернізму і художніх практиках початку XXI ст. Мистецтво і концептуальні принципи модернізму і постмодернізму стали прологом до формування феномену сучасного образотворчого мистецтва як віАображення актуацьних тенденцій культурної, Ауховної, соціальної сфер часу.

\section{$\Lambda$ ітература}

1. А^фьорова 3. Візуальне мистецтво кінця XX - початку XXI ст.: Аис... А-ра наук: 26.00.01. Харків, 2008.

2. А^фьорова 3. Термінологічні ігри щодо візуальних мистецтв // Мистецтвознавство України: зб. наук. пр. / ІПСМ НАМУ. Київ, 2009. Вип. 10. С. 166-170.

3. Беньямин В. Произведение искусства в эпоху его технической воспроизводимости. М., Медиум, 1996. C. 66-91.

4. Бодрийяр Ж. Заговор искусства // URL: http://moscowartmagazine.com/issue/70/article/1496 (Аата обращения: 04.11.2020). 
5. Бычков В., Маньковская В., Иванов В. Триалог: Разговор первый об эстетике, современном искусстве и кризисе культуры. М.: ИФ РАН, 2007. 240 с.

6. Вартанова Е. Медиаэкономика зарубежных стран: глоссарий. М.: Аспект Пресс, 2003. 335 с.

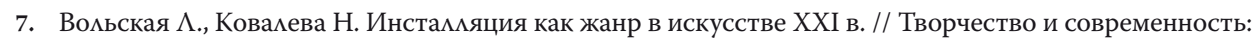
сетевое издание. 2018. URL: https://cyberleninka.ru/article/n/installyatsiya-kak-zhanr-v-iskusstve-hhi-v/ viewer (Аата обращения: 04.11.2020).

8. Аелез Ж. Переговоры. 1972-1990: сборник / пер. с фр. и вступ. ст. В. Ю. Быстров. Санкт-Петербург: Наука, 2004. 240 с.

9. Жевак А. Тенденции развития современного изобразительного искусства второй половины XX - начала XXI вв.: культурфилософский анализ // Аис. ... канА. филос. наук: 09.00 .13 «Философская антропология, философия культуры». Саратовский госуА. ун-т им. Н. Чернышевского, 2015.

10. Копієвська О. Трансформаційні процеси в культурних практиках України: глобальний, глокальний контекст та цокальні особливості (кінець XX - початок XXI ст.) // Аис. ... А-ра культурології: 26.00.06. Київ, Національна академія керівних кадрів культури і мистецтв, 2018.

11. Маклюэн М. Законы медиа // История фикософии. Вып. 8. Москва, ЦОП Института философии PAH, 2001. C. 124-163.

12. Мерло-Понти М. Феноменология восприятия, 1945 / пер. с франц. под реА. И. ВАовиной, С. Фокина. Санкт-Петербург: Ювента, Наука, 1999. С. 185.

13. Ортега-и-Гассет Х. Восстание масс // Аегуманизация искусства: сборник. М.: Радуга, 1991. С. 40-229

14. Федоров А. Словарь терминов по медиаобразованию, медиапедагогике, медиаграмотности, медиакомпетентности. Таганрог: ИзА-во Таганрог. гос. пеА. ин-та, 2010. 62 с.

15. Эко У. Инновация и повторение. МежАу эстетикой модерна и постмодерна / Фикософия эпохи постмодерна. Минск, 1996. С. 48-73.

16. Эко У. Открытое произведение. М.: Академический проект, 2004. С. 102-135.

17. Югай И. Медиа искусство: истоки, специфика, художественные стратегии // Аис. ... Аоктора искусствоведения: 17.00.09. Санкт-Петербург, 2018.

18. Benjamin W. The Theory of Criticism. Cambridge, Massachusetts London, England, 1966. P. $217-218$.

19. Danto A. The Work of Art and the Historical Future // The Madonna of the Future: Essays in a Pluralistic Art World. University of California Press, 2001. P. 176.

20. Higgins D. Synesthesia and Intersenses: Intermedia // Something Else Newsletter, 1967. Vol. 1. № 1. 4 p.

21. Merleau-Ponty M. Cezanne's doubt // The Merleau-Ponty aesthetics reader: philosophy and painting / ed. by G. Johnson. Illinois: Northwestern University, 1993. P. 59-75. 


\section{References}

1. Alf orova Z. Vizual`ne my`stecztvo kincya XX — pochatku XXI st.: dy`s... d-ra nauk: 26.00.01. Xarkiv, 2008.

2. Alf orova Z. Terminologichni igry` shhodo vizual`ny`x my`stecztv // My`stecztvoznavstvo Ukrayiny`: zb. nauk. pr. / IPSM NAMU. Ky’yiv, 2009. Vy’p. 10. C. 166-170.

3. Benyamin V. Proizvedenie iskusstva v epohu ego tehnicheskoy vosproizvodimosti. M., Medium, 1996.

S. 66-91.

4. Bodriyyar Zh. Zagovor iskusstva // URL: http://moscowartmagazine.com/issue/70/article/1496

(last accessed: 04.11.2020).

5. Byichkov V., Mankovskaya V., Ivanov V. Trialog: Razgovor pervyiy ob estetike, sovremennom iskusstve i krizise kulturyi. M.: IF RAN, 2007. $240 \mathrm{~s}$.

6. Vartanova E. Mediaekonomika zarubezhnyih stran: glossariy. M.: Aspekt Press, 2003. 335 s.

7. Volskaya L., Kovaleva N. Installyatsiya kak zhanr v iskusstve XXI v. // Tvorchestvo i sovremennost: setevoe izdanie. 2018. URL: https://cyberleninka.ru/article/n/installyatsiya-kak-zhanr-v-iskusstve-hhi-v/viewer (last accessed: 04.11.2020).

8. Delez Zh. Peregovoryi. 1972-1990: sbornik / per. s fr. i vstup. st. V. Yu. Byistrov. Sankt-Peterburg: Nauka, 2004. $240 \mathrm{~s}$.

9. Zhevak A. Tendentsii razvitiya sovremennogo izobrazitelnogo iskusstva vtoroy polovinyi XX - nachala XXI vv.: kulturfilosofskiy analiz // dis. ... kand. filos. nauk: 09.00.13 «Filosofskaya antropologiya, filosofiya kulturyi». Saratovskiy gosud. un-t im. N. Chernyishevskogo, 2015.

10. Kopiyevs`ka O. Transformacijni procesy` v kul turny`x prakty’kax Ukrayiny`:

global `ny`j, glokal `ny`j kontekst ta lokal `ni osobly`vosti (kinecz` XX - pochatok XXI st.) // dy`s.... d-ra kul turologiyi: 26.00.06. Ky`yiv, Nacional 'na akademiya kerivny’x kadriv kul 'tury` i my`stecztv, 2018.

11. Maklyuen M. Zakonyi media // Istoriya filosofii. Vyip. 8. Moskva, TsOP Instituta filosofii RAN, 2001.

S. 124-163.

12. Merlo-Ponti M. Fenomenologiya vospriyatiya, 1945 / per. s frants. pod red. I. Vdovinoy, S. Fokina. SanktPeterburg: Yuventa, Nauka, 1999. S. 185.

13. Ortega-i-Gasset H. Vosstanie mass // Degumanizatsiya iskusstva: sbornik. M.: Raduga, 1991. S. 40-229

14. Fedorov A. Slovar terminov po mediaobrazovaniyu, mediapedagogike, mediagramotnosti, mediakompetentnosti. Taganrog: Izd-vo Taganrog. gos. ped. in-ta, 2010. $62 \mathrm{~s}$.

15. Eko U. Innovatsiya i povtorenie. Mezhdu estetikoy moderna i postmoderna / Filosofiya epohi postmoderna. Minsk, 1996. S. 48-73.

16. Eko U. Otkryitoe proizvedenie. M.: Akademicheskiy proekt, 2004. S. 102-135.

17. Yugay I. Media iskusstvo: istoki, spetsifika, hudozhestvennyie strategii // dis... doktora iskusstvovedeniya: 17.00.09. Sankt-Peterburg, 2018.

18. Benjamin W. The Theory of Criticism. Cambridge, Massachusetts London, England, 1966. P. 217-218.

19. Danto A. The Work of Art and the Historical Future // The Madonna of the Future: Essays in a Pluralistic Art World. University of California Press, 2001. P. 176.

20. Higgins D. Synesthesia and Intersenses: Intermedia // Something Else Newsletter, 1967. Vol. 1. № 1. 4 p.

21. Merleau-Ponty M. Cezanne's doubt // The Merleau-Ponty aesthetics reader: philosophy and painting / ed. by G. Johnson. Illinois: Northwestern University, 1993. P. 59-75. 


\section{Миронова Т. В. Понятийно-категориацьная система современного украинского искусства в новой эстетической парадигме XXI века}

Аннотация. Обновление тематического и стилистического разнообразия визуальных арт-проявмений обусловило обновмение понятийно-терминологического и категориального аппаратов современного искусствоведения. Современное искусство один из наиболее динамичных культурных феноменов современности и его исследование постоянно требует обновления осмысления и методов анализа Аля ориентации в огромном количестве его видов, направлений и жанров. Развитие современного искусства неразрывно связано с техническим прогрессом, цифровыми инновациями, при этом в своем традиционном направмении оно постоянно находится в поиске новых форм, придумывает новые жанровые системы, играет с контрастами и экспериментирует с материалами. Все эти процессы интересны ученым и в первую очередь Аолжны быть регламентированы определенной терминологической системой.

ОАним из первоочередных в теоретическом дискурсе эстетики и философии искусства остается вопрос формулировки дефиниции «современное искусство». В процессе формирования понятийно-категориального аппарата современного изобразительного искусства важную роль сыграли философские исследования Ж. Бодрийяра, М. Мерло-Понти, Х. Ортеги-и-Гассета и Ар. Теоретические основы, предложенные в рамках их философских рефлексий, получили развитие в искусстве постмодернизма и художественных практик начала XXI века. Искусство и концептуальные принципы модернизма и, особенно, постмодернизма мегли в основу формирования феномена современного искусства как отражения актуальных тенденций кумьтурной, духовной, социальной сфер времени.

КАючевые слова: терминологический аппарат, современное искусство, contemporary art, технологический прогресс.

\section{Mironova $T$. $V$. Conceptual and categorical system of contemporary Ukrainian art in the new aesthetic paradigm of the twentieth century}

Abstract. The renewal of the thematic and stylistic diversity of visual art manifestations led to the renewal of the conceptual, terminological and categorical apparatuses of contemporary art history. Contemporary art is one of the most dynamic cultural phenomena of our time, so it needs to be updated constantly study reflection and analysis tools, to its orientation in the huge number of species, trends and genres. The development of contemporary art is inextricably linked with technological progress, digital innovations, and in its traditional direction, it is constantly looking for new forms, inventing new genre systems, playing with contrasts and experimenting with materials. There is no doubt that all these processes are of interest to modern scholars and above all must be regulated to some terminological system.

One of the priorities in the theoretical discourse of aesthetics and philosophy of art is the question of formulating the definition of "contemporary art". The philosophical reflections of J. Baudrillard, M. Merleau-Ponty, J. Ortega y Gasset, and others played an important role in the formation of the conceptual and categorical apparatus of modern fine arts. The theoretical foundations proposed in the framework of their philosophical reflection were developed in the art of postmodernism and artistic practices of the early XXI century. Art and conceptual principles of modernism and postmodernism have become a prologue to the formation of the phenomenon of modern art as a reflection of current trends in cultural, spiritual, social spheres of time.

Keywords: terminological apparatus, contemporary art, contemporary art, technological progress. 